Ocean \& Coastal Management

September 2008, Volume 51, Issue 10, Pages 689-

700

http://dx.doi.org/10.1016/j.ocecoaman.2008.07.009

(c) 2008 Elsevier Ltd All rights reserved.
Archimer, archive institutionnelle de l'Ifremer http://www.ifremer.fr/docelec/

\title{
Public-aided crises in the French fishing sector
}

\author{
Benoit Mesnil $^{\mathrm{a}, \text { * }}$ \\ a Ifremer, Département EMH, Rue de l'Ile d'Yeu, BP 21105, F44311 Nantes, France \\ *: Corresponding author : B. Mesnil, Tel.: p33 240374 009; fax: p33 240374 075, email address: \\ Benoit.Mesnil@ifremer.fr
}

\begin{abstract}
:
According to the media the French fishing industry has been in permanent state of crisis for the last 40 years. This paper recounts the events surrounding three major episodes of crises (late 1970s, mid1990s, and early 2000s), and the measures taken by governments to resolve them. Invariably, these involved the distribution of sizeable amounts of public aids, in different forms, to the fishing sector. The efficacy of the subsidy programmes is discussed with reference to the goals stated by their proponents, regarding trade balance, competitiveness, profitability, employment and safety. Overall, the massive aids granted to the sector (comparable with the gross value of landings, annually) have not achieved the stated objectives and, paradoxically, have been a key factor in the eruption of subsequent crises, notably because they were granted without conditions of genuine changes in the industry's practices. The supreme paradox is that the succession of turbulent demonstrations over the years was the result of aid programmes devised with the overriding objective of preserving social peace.
\end{abstract}

Keywords: fisheries policies; subsidies; France 


\section{Introduction}

Have you noted how often fisheries and their management get associated with words that sound negative or dramatic? Competition-a normal feature in market economies- promptly attracts the word "conflict" in public discourse or in the media when fisheries are implicated. Meetings between the fishing industry and managers, or between EU fishery ministers and the European Commission are commonly depicted in similarly confrontational terms, as are relations within the industry itself even at the local scale. Although competition for natural resources (oil, water or minerals) may well be a driver behind some current or past wars, it is seldom named as such. In contrast, there seems to be little hesitation to use such an extreme term for fisheries conflicts, e.g. for the "cod war" at Iceland in the 1970s or the "turbot war" off Canada in 1995 [1]. When they talk about fisheries management, observers from all quarters (fishers, scholars, journalists, and NGOs) seem to be irresistibly attracted by the word "failure". Evidently, this is how many tend to qualify the outcome of the EU Common Fisheries Policy (CFP): in its Green Paper [2] preparing for the 2002 reform the European Commission itself admitted that the policy had not delivered several of its stated goals, and a recent report by the European Court of Auditors [3] used blunt language to conclude on a plain failure of the policy. However, it is common for such broad framework policies to aspire at a mix of biological, economic, social and political objectives that are quite hard to reconcile, with the consequence that what some see as a failure is seen as a success by others [4,5]. Last, but not least, in this litany is the word "crisis". As pointed out by Beddington et al. [6], and many others, the public perception of fisheries, globally or locally, is one of recurring crises. Certainly, a survey of French newspapers over the recent decades leaves one with the uncomfortable impression that marine fisheries and crises are just one and the same thing.

It is somewhat puzzling that fishers and their trade magazines are not the least vociferous in using these words that carry a poor image of their industry. In many instances, they are elements of a discourse in which the fisheries sector poses as a victim of "the system" - that is of everybody else. Yet, in many countries, the sector receives significant assistance from the rest of the nation through "government financial transfers" (the OECD terminology for subsidies) in the form of direct payments or special exemptions. Bewildering estimates of fisheries subsidies at the global level are floating around (e.g. Ref. [7]), but it is hard to interpret them properly at such a broad scale. In the EU, national aids are augmented with Community funds and in total the fish catching sector is comparatively more aided than many others, apart agriculture.

France is one of these countries where state aids to the fishing sector are regarded, both by public bodies and the industry, as an intrinsic element of the business. As we will see, sizeable amounts of money are distributed year on year, often with the intention of curing the structural deficiencies that caused the crisis of the day. Nevertheless, serious crises keep on occurring at an unabated pace, and this raises the question of whether these aids have the intended effect. An exploration of this question is the main purpose of this essay. The material is drawn from a survey of the French and international fishing press, and of official documents when publicly available. Since most readers are presumably unfamiliar with the context, two prologue sections recall the events and measures adopted at three periods of major crises, and present data about the public aids granted to French fishers ${ }^{1}$. The efficacy of the aid policies, with respect to the goals stated by their proponents, is then discussed.

\section{A chronicle of crises}

A description of each of the fishery-related events that were labelled as a crisis in the media headlines over the last 30 years would probably require several volumes of this journal. The choice has been made here to select three periods, roughly ten years apart, each centred on a major crisis - the real gallic ones, with clamorous demonstrations, barricades, blazes in streets, etc. Before proceeding, however, it may be helpful to set the stage with a brief reminder on post-war developments in France.

\footnotetext{
${ }^{1}$ Monetary figures are in nominal values throughout. Comparisons are made with the value of contemporaneous landings to provide a sense of the significance of aids. At the time of change in currency, the exchange rate was roughly FF (French Franc) 6.5 for one euro (and likewise for the ECU when this was in use). $\mathrm{M}$ is used for million (to avoid confusion with $\mathrm{m}$ for metre), and bn for billion.
} 


\subsection{Background: the capacity build-up}

Like a number of European countries, France found itself at the end of World War II with devastated fishing fleets and infrastructures, disrupted trade circuits and a general shortage of food for people. The restoration of efficient fish capture and processing industries was thus viewed by governments as an utmost necessity and, in those times of planned economy, up to seven five-year plans were put in place with explicit targets in terms of fleet tonnage or even of mass of fish to be caught [8]. Most of these plans deliberately favoured the industrial sector, an administrative classification which in France means the larger (>30 m), company-owned vessels on which crews have a minimum guaranteed salary plus premiums depending on the revenue of each trip $^{2}$ (in contrast to the artisanal category designating boats owned by the skipper or by cooperatives with crews paid under a share system ${ }^{3}$ ). In part, this prioritisation reflects the clout of a small club of relatively homogeneous fishing companies whose affluent executives could talk on equal footing with top government officials, whereas the geographical dispersion and fragmented structure of the artisans hampered their ability to come up with clear and consensual proposals. Moreover, the dominant doctrine of the time was that to be modern and efficient, a business had to be capital intensive, concentrated and integrated. Since the industrial sector was the prominent actor in the operation of distant water fisheries in the North Atlantic (and for tropical tuna), another key factor was that investments in large modern vessels were seen as an essential mean to defend a French access to the traditional fishing grounds, which otherwise might be lost to its foreign competitors who also benefited from government-funded modernisation programmes. Indeed, this concern about access was still quite vivid during the lengthy period of CFP negotiations leading to the resource sharing agreement in 1983, and France was not unique among the $\mathrm{EU}^{4}$ partners in subsidising its fleet to bolster its track records.

It is only after the mid-1970s that the government (and the EU) began to provide more substantial support to the artisanal sector. A factor was the realisation that its landings were similar to those of the industrials in mass - and a fair amount larger in value - with a broader diversity of species. In addition, France was in the process of devolving more powers to the Regions (established in 1972) and, in particular, these were granted authority over development programmes for the artisanal sector. A major attraction of the coastal Regions towards the artisans was that they made up the bulk of maritime employment, and a sizeable amount of voters by the way. A drawback of this move was that the Regions tended to implement their programmes independently or even in a competition with their neighbours, priding themselves in announcements that they helped their fishers more than others, by which they meant that they aided the construction of more new vessels ${ }^{5}$. On top of direct subsidies, an important aid for new constructions was in the form of preferential loan rates ${ }^{6}$ (the difference with market rates being charged to taxpayers) on up to $85 \%$ of the unsubsidised cost. In those times when

\footnotetext{
${ }^{2}$ Not to be confused with the Northern Europe meaning of fishing for oil and meal reduction which, according to the French (and UK) fishers, is the cause of all their troubles including the poor state of stocks in the southern Bay of Biscay.

${ }^{3}$ Being classified as artisanal does not imply that a vessel operates in coastal waters or with low tech methods; some are up to $25 \mathrm{~m}$ long, use large trawls and can fish very far from their home port. In some periods, the definition involved criteria of maximum length or tonnage for the vessel, but the rule seems to have been overridden by the exceptions. In the end, being classified as an artisan is very much left to the discretion of the administration. In international conventions 'artisanal' often means subsistence fisheries, but this is clearly inappropriate for the French case.

${ }^{4}$ Strictly speaking, the European Community prior to the Maastricht Treaty, but EU is now universal language to designate the political entity and its institutions; the acronym EC is used here for the European Commission.

${ }^{5}$ Such competition was still more manifest after 1982, when further steps were taken to empower the Regions.

${ }^{6}$ With a monopoly granted to a network of regional banks, Crédit Maritime (nicknamed 'the seamen's bank'), an emanation of the artisanal and cooperative movement. The boards of the local branches comprising a strong representation of the industry have actively promoted the expansion of the fleet, sometimes against the warnings of the professional bankers. Occasionally, when faced with difficulties, the bank itself has received state aids.
} 
inflation rates in France exceeded $15 \%$, one could actually make money by just borrowing at the aided rates (around 5\%), and the bigger the loan, the larger the gain [9]. Hitherto part of the reservations against aids to the smaller vessels (under $12 \mathrm{~m}$ ) had arisen from concerns that the coastal grounds were in a process of being overfished -with adverse impacts on offshore stock componentstogether with safety reasons [8]. The motto behind the national and regional policies has thus been to favour larger vessels, capable of fishing further offshore and more flexible in terms of gears. In fact, the public aids have mostly favoured the most intensive (in capital and energy) fishing method trawling - and the policies can be summarised as an industrialisation of the artisanal sector.

Overall, the result of the public aid policies was that, at the dawn of the crises era described below, France had a modern fleet which was strong in fishing capacity (Figs. 1 and 2) but fragile financially due to huge capital repayments. The concept that state, or EU, interventions - with monies, not controls - were part of the natural order of things in the fishing business was also established.

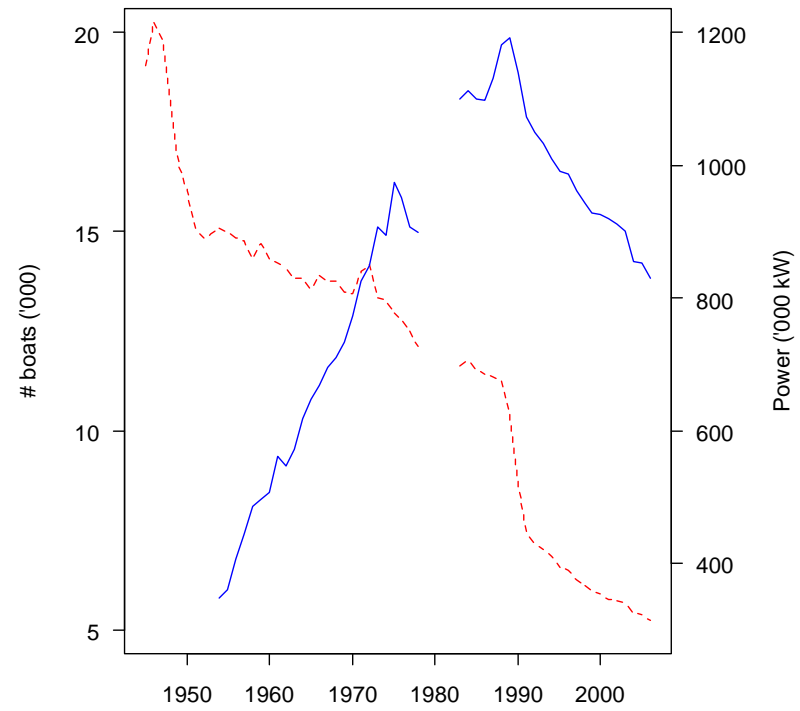

Fig. 1. Post-war development of the French metropolitan fleet: number of vessels (dashed line, left $y$ axis) and aggregate engine power (solid line, right y axis). Data 1985-1978 from Bulletin Statistique des Pêches Maritimes compiled by Meuriot [8], 19832006 from Ifremer-SIH. Dubious intermediate data ignored.

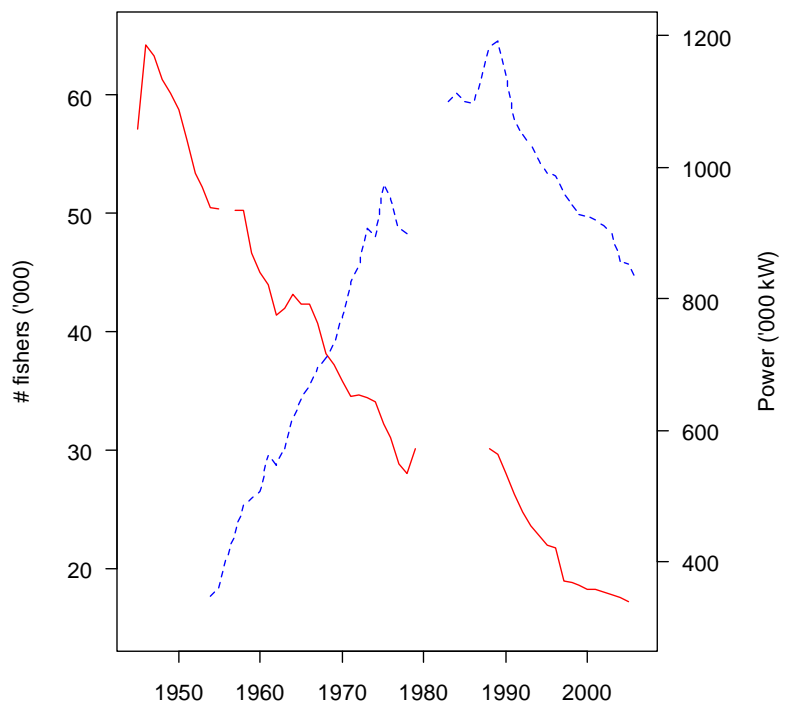

Fig. 2. Post-war trends in the number of registered fishers (skippers or crew, employed at least one day; excluding overseas territories and shellfish farmers; solid line, left y axis). Plot of aggregate power (same as in Fig. 1; dashed line, right y axis) repeated for comparison. Data 1945-1979 from Meuriot [8], 19882005 from Affaires Maritimes-DSI fact sheets; employment data 1980-1987 from various sources were too inconsistent for inclusion.

\subsection{Late 1970s}

At the start of 1974 the French fishing magazines predicted a brilliant outlook. Landings in all ports in 1973 had broken historical records - in nominal value if not in weight- and the major fish stocks showed no sign of distress. By April, however, alarms were raised about the booming price of oil, following the tensions in the Middle East, to which the government responded by a bonus on the 
existing fuel price aid ${ }^{7}$. By September, the price of fuel had quadrupled compared to 1972 and the price of nylon netting was to follow suit. Moreover, given that the industrial fleet was making about $65 \%$ of its landings from UK waters and another $25 \%$ from other foreign waters, the industry was getting anxious about the outcome of the Caracas conference, presaging the codification of 200-mile EEZs, and about the tenacious attitude of the UK government against the notion of equal access up to the beaches in Community waters. Lastly, landings in 1974 fell by some $10 \%$, adding to the sense of despair within the industry. Then, in February 1975, a period of fair weather permitted massive catches in Northern Europe, with the effect of depressing landing prices, which sparked off a series of riots and blockades in French harbours ${ }^{8}$.

The government responded with an arsenal of aids: doubling of the fuel aid, subsidies to Producer's Organisations (POs) for the landing price support, calls on the EC for rising the withdrawal prices, ban on non-EU imports, extra aids and low cost loans for the artisans and the industrial companies. Some of these "emergency measures" became instituted, notably the extra fuel aid. Although the price of oil - which continued to rise- was clearly an issue for the industry, it is noteworthy that officials in France and in several of its neighbours pointed at the drop in fish price as the main cause of the crisis $^{9}$. Beside calls on the EC for restrictions of cheap imports and increase of Community minimum landing prices, the French government pressed the industry to establish a fund (FIOM), with an interprofessional management board, tasked with enhancing the regulation of, and support to the national market. The draft decree stipulated that state contributions to the fund would be optional - a clause that disappeared in the final text after negotiations with the industry. In effect, the state aids granted through this fund during 1976-1983 were more than double (in constant francs) the market aids during 1963-1975 [8].

Except for an episode in 1976, when the Prime Minister awarded a supplemental aid (on top of the regular budget) of FF $127 \mathrm{M}$-including an extra $100 \mathrm{M}$ for fuel aid - which he claimed represented nearly $10 \%$ of the landed value ${ }^{10}$, officials in charge at the time were brave enough to defy recurring reproof by the industry (and MPs) that the granted fuel aid was not up to fishers' wishes. One reason was the fear that other professions (e.g. taxi or lorry drivers) would ask similar favours. Another reason is that direct aids to enterprises became illegal under EU law as of January 1976, which brought about a funny subterfuge: following negotiations with the EC, France obtained that dressing up the fuel aid as an aid to regional employment would be compatible with the Treaty; hence people were urged to call it "aid to sustain employment" despite the fact that it would be calculated on the basis of the actual fuel consumption [10]. The part of truth in this is that, with share wages, fuel expenses are partly borne by the crew so the aids have some social effects. In passing, the industry was rehearsing the discourse - to be heard many times later on - that consumers should contribute to operating costs borne by fishers, e.g. by a tax on fish or on gas for cars. In contrast, the industry was less insistent in claiming aids for new vessels during 1974-1978, as it was mostly preoccupied with rising costs (both for building and operation of vessels), loss of access to traditional fishing grounds, uncertainties about the status of UK waters and the first serious implementations of catch quotas. Indeed, the mood in the industrial sector was about contraction rather than expansion of the fleet: several insolvent companies sold out a number of vessels, to the point that local MPs and industry spokespersons voiced alarms about the loss of seamen jobs and the doom of some harbours. Some aids ear-marked for investments were redirected to support the survival of fishing companies, with the condition that they keep their recent vessels in activity for at least five years. The situation in the artisanal sector was less distressing, as evidenced by a ministerial statement in June 1979 that projects for the construction of 170 vessels (with state and regional aids) had been approved over the previous twelve months, and that the plan was to renew $10 \%$ of the fleet each year.

\footnotetext{
${ }^{7}$ On top of the tax exemption that had been granted to fishing vessels since 1949. The absence of taxes implies that any increase in the price of crude oil is immediately reflected in the price of fuel charged to fishers.

${ }^{8}$ For the same reasons the British fishermen also blocked ports for a few days in April and obtained an aid per day fished, a form of fuel aid in all but name.

${ }^{9}$ Spain was rather unique in launching a massive decommissioning scheme to save on the nation's oil bill.

${ }^{10}$ He probably meant wetfish only. The total value of landings was about FF 4.6 bn.
} 
In April 1980 the minister announced that state aids to the fishing sector were increased by some $60 \%$ over $1979^{11}$, but again refused to augment the fuel aid and was adamant that support to fishing companies was conditional on clear commitments on their part regarding initiatives to improve their profitability and financial structure. In response the industrial companies approached the unions to negotiate a reduction of the legal crew size (20-22 men depending on vessel size) by two men. The incensed industrial crews went on strike and were joined by the artisanal fishers in a common protest against the cost of fuel. As a result, all French ports, fishing and commercial alike, were blocked for several weeks during August and September ${ }^{12}$ and the government had to summon the Navy to force the passage free. A package of additional measures was proposed to resolve the crisis among which: extra funds for FIOM and POs for the fish price support scheme, stiffer quality controls on imports, supplemental loans for the modernisation of the artisanal fleet with an extension to under 12-m vessels, ... and vows to have the CFP established by the end of 1980. In this respect, it is striking to note the faithful belief of most actors at the time that the CFP settlement would immediately and by itself result in a recovery of the fish stocks - and for sure by 1985, some said-while they saw no contradiction between such hopes and their sustained efforts to defeat every conservation measure proposed by the Commission. The obsession, anyway, was that the French fleet should be strong enough to take its slice of the would-be cornucopia. This came first among the goals stated by the minister in his January 1981 speech, in which he announced that the aids to the sector would amount to FF 306 M (vs. 200 M in 1980, finally, and 109 M in 1979).

In May 1981, general elections resulted in a president and government from a different majority, and fisheries became supervised by a newly created Ministry of the Sea with an MP from a stronghold of the artisanal sector at the wheel. One of his first measures was to augment the direct fuel aid with a mechanism whereby any increase in the market price of fuel exceeding the inflation rate (around $10 \%$ at the time) would be compensated by a state aid. More significantly, in 1982 he launched a five-year investment programme with measures to aid the construction of around 25 industrial and 100 artisanal $^{13}$ new boats per year (during the previous eight years an average of 68 boats had been built annually with state aids). It is ironic to read today that the administration's working hypothesis - well received by the industry, journalists wrote- in the draft programme postulated an improvement in catch per unit effort of $10 \%$ in five years [11]; not quite what happened. The programme was regularly reinforced by the state budget approved by the Parliament, even after March 1986 when conservatives returned to power. State aids were augmented by subsidies from the Regions, and from European funds which themselves increased in favour of the artisanal sector in 1984-1985, so that in some cases around $45 \%$ of the investment could be covered by subsidies of various kinds, whereas investors were required to bring as little as $8 \%$ from their own purse. The net result of the policy was a spectacular increase in fishing capacity, not so much in terms of overall number of vessels -which continued to decrease - than of length and engine power of the boats (Figs. 1-3): the average power per vessel rose from some $87 \mathrm{~kW}$ in 1980 to $132 \mathrm{~kW}$ by 1990. This was in complete disregard for the Community Multi-Annual Guidance Plans (MAGP; see details in Ref. [12]) for 1983-1987 —which required a stabilisation of capacity - and for 1987-1991 — which required a $2.4 \%$ decrease in power about which both the administration and the media kept silent until mid-1988.

\footnotetext{
${ }^{11}$ To FF $175 \mathrm{M}$, of which $53 \mathrm{M}$ for fuel, $56 \mathrm{M}$ for new boats, $36 \mathrm{M}$ for FIOM and $30 \mathrm{M}$ of relief aid to enterprises. For comparison, the value of landings in 1979 was about FF 4.8 bn.

${ }^{12}$ British cross-Channel ferry companies sued the French authorities for damages (right at the peak of the summer season); it took nearly ten years for the government to reimburse them. The exact cost for taxpayers has not been made public.

${ }^{13}$ In the initial draft prepared by the industry the wish list summed up to 128 new boats per year. A clear message of the industry representatives was that aids to the smaller inshore trawlers should be limited, and a preference given to boats over $16 \mathrm{~m}$; this orientation was retained in the final plan.
} 


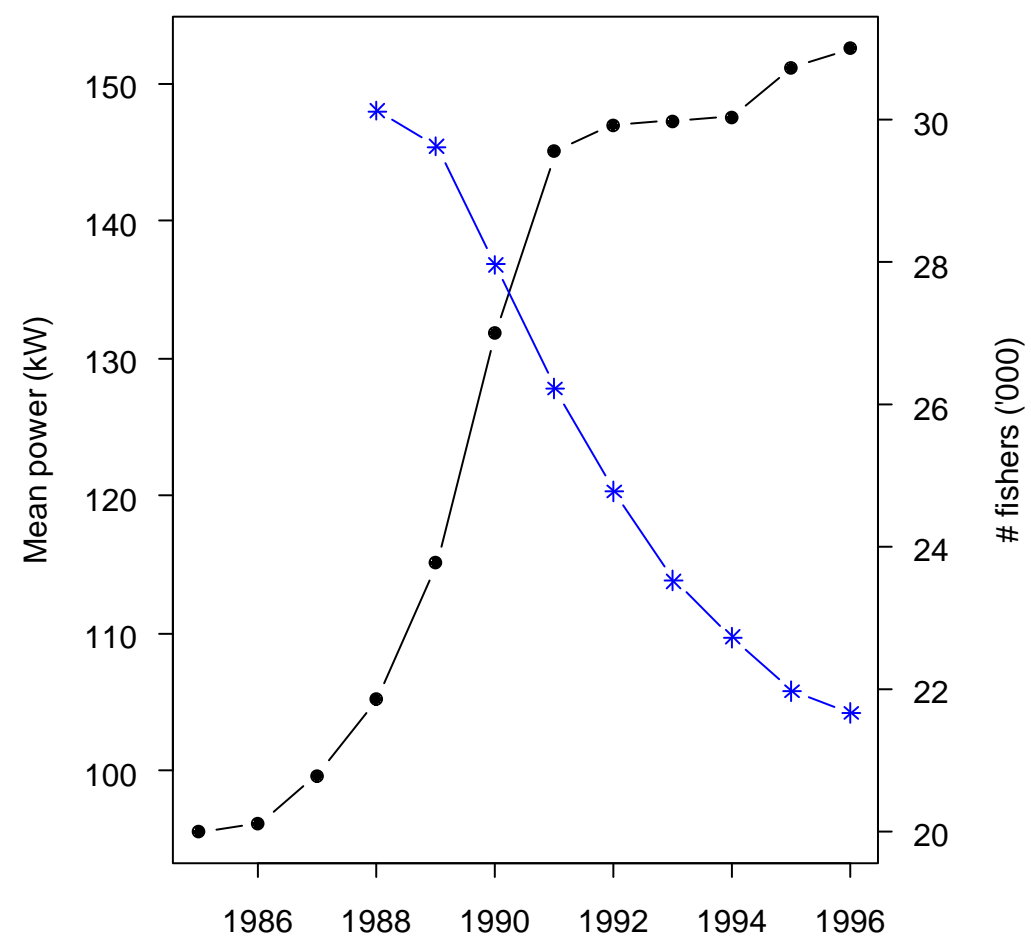

Fig. 3. Zoom view of the labour-capital trade-off during the 1980-1990s (the boom of the artisanal sector): mean power per vessel (solid circles, left y axis) vs. number of fishers (stars, right y axis). Metropolitan fleet only; same sources as Figs. 1 and 2.

\subsection{Mid-1990s}

This period starts with a radical U-turn known as the "Mellick Plan" (after the minister's name), a decommissioning program aiming at removing some $10 \%$ of the fleet's power in one year, allegedly to comply with the MAGP and to lift the ban on all investment aids (national or otherwise) imposed by the EU in case the MAGP targets were exceeded. The buyback plan reached its target but may not have had the expected effects on actual capacity: the 1000 odd vessels withdrawn were mostly old (74\% over 20 years) and small ( $82 \%$ under $12 \mathrm{~m}$ ), and a number only had part-time activity if any [13]. As a consequence the fleet's structure was more than ever concentrated around the recent, capital intensive, energy hungry and costly super-artisanal "killing machines", a feature that paved the way to the incoming crisis. In balance, a clear benefit of the plan was its strong and durable psychological impact: all actors in fishing circles learnt to live with the idea that public aids could be used to harness the fleet rather than always expand it ${ }^{14}$, and even though modernisation has continued to be on the agenda (still today) claims to have boats built by the hundreds have not been heard again.

The next crisis which erupted in February 1993 had been lurking for a while, due to declining landings, low prices, non-competitiveness of French products on export markets - due in part to devaluations of the UK pound, Irish punt, Italian lira and a few other currencies. By the end of 1992, alarms were raised in the media about the rising number of fishing enterprises, and by extension of seamen's families, unable to repay their loans. A further drop in prices in early 1993, blamed on cheap imports of whitefish from Russia, Norway and the US, precipitated a wave of violent demonstrations

\footnotetext{
${ }^{14}$ In total, the cost of the Mellick Plan for the state, the Regions and the Departments was around FF $190 \mathrm{M} ; 70 \%$ of which were eventually reimbursed by the EU.
} 
that lasted over three weeks, marked by the rampage through the Rungis (near Paris) wholesale market in February, and destructions of "unfairly" imported seafood in ports, highways, cold stores and supermarkets. An immediate response of the ministry was to issue emergency aids to indebted families, and to POs for market support (only one-third of that aid was effectively paid). It also called on the Commission to raise the minimum price of imports from third countries temporarily, as stipulated in the CFP 1992 market regulation, but failed to get the support of other Member States in his plea to have this extended until the end of the year. Management of the crisis was muddled as general elections took place in March, resulting in a change of government and a new minister inaugurating the paired agriculture and fisheries portfolio. He promptly went on with a suite of aids: FF $42 \mathrm{M}$ in March — promised by his predecessor between the two rounds of the elections- mostly in the form of direct aids to skippers and crews; $30 \mathrm{M}$ in April to POs exhausted by their expenditures on withdrawals; $80 \mathrm{M}$ in May (of which $66 \mathrm{M}$ for price support); $164 \mathrm{M}$ in September (re-scheduling of subsidised loans, price support). Noticeably, in October he introduced the rebate on the contribution to the pension system paid by fishers as a novel form of state intervention, on which we will expand later. Initially, it was restricted to the contribution by the artisanal enterprises (-30\%, worth about FF $40 \mathrm{M}$ ) but was extended during 1994 to that by artisanal crewmen and then to that by industrial companies. In total, the government granted some FF $480 \mathrm{M}$ in various ways between March and September $1993^{15}$.

Clearly, this was ineffective to cure the problem: fishers were still unable to cover their costs and returned on strike in the whole country in February 1994. And again, scenes of pillage by irate fishers in Rungis, in supermarkets, in cold stores and in fish processing plants could be seen on TV. The government's response was very much the same again: call on the Commission to apply the alleged "Community preference principle" (i.e. barriers on imports, refused by most EU states), and financial aids of all kinds to the tune of FF $300 \mathrm{M}$ (including provisions for decommissioning). The minister commissioned an audit on the state of the artisanal fleet [14], which concluded that 270 of the $160012-25 \mathrm{~m}$ boats had serious but solvable problems whilst 100 were objectively bankrupt. Based on this, in February 1995, he issued another plan aimed at loan adjustments combined with welfare measures, at an estimated cost of FF $330 \mathrm{M}$ of which $180 \mathrm{M}$ to be borne by the state on top of the regular 1995 budget. In an internal bulletin ${ }^{16}$ the ministry stated that FF 1.5 bn had been granted since April 1993 in financial, social and market aids by the government, to which one should add aids by the Regions and other public institutions.

Although the industry welcomed most measures, it maintained its view that the crisis was due to poor prices and cheap imports and criticised the inadequacy of measures in that area (its extravagant claim that the state should pay for the difference between market prices and the higher prices needed to keep businesses afloat was refuted, which spurred resentment). This raises a question: if the issue was one of prices, which were similar across Europe, how is it that it resulted in a major crisis in France and not elsewhere? Why did the front page of the British weekly Fishing News of 20 January 1995 proclaim in big bold font that 1994 was a record year in value for NW Scotland ports while the French papers were all doom and gloom? Although peculiarities in their markets may have resulted in lower prices for French producers, a specific feature of the French industry then was its indebtedness resulting from the massive investment programmes of the preceding years, which made it very fragile to incidents affecting the economic or natural (fish stocks, weather) environment. The move towards a 'heavy industry' is reflected in the mean power per vessel which continued to rise during that period (Fig. 3). This root cause of the crisis is also recognised in the audit report [14], if only implicitly as the civil servants who wrote it took great care with language that might implicate the liability of public authorities in a process that they had largely led and funded. The unbridled overinvestment of that period was also behind the next row of crises, when fuel cost problems returned to the fore.

\footnotetext{
${ }^{15}$ Libération, February 4, 1994. For reference the landed value of marine fisheries in those years was around FF 6 bn.

${ }^{16}$ Bulletin d'Information du Ministère de l'Agriculture, May 1995 : 10-18, titled « 100 measures to make fisheries a full-fledged economic sector » [my literal translation].
} 


\subsection{Early 2000s}

The drop in profits and wages due to a sharp increase in the price of crude oil during 1999-2000 caused a series of blockades of major ports to force the government on fuel aids. Interestingly, the initiators of several of these riots were fishers from the Western Mediterranean area: in the early 1970s they had instituted through their traditional fishers' guilds a licensing system for trawlers that set a maximum of $430 \mathrm{hp} \mathrm{(316} \mathrm{kW)} \mathrm{for} \mathrm{engine} \mathrm{power} \mathrm{but,} \mathrm{as} \mathrm{now} \mathrm{confessed} \mathrm{by} \mathrm{industry} \mathrm{delegates,} \mathrm{the}$ power of the recently built trawlers was rather in the range 1600-2000 hp, implying much higher running costs than if they had complied with their own rules ${ }^{17}$. In fear of disruptive riots the government conceded two packages of aids -FF $75 \mathrm{M}$ in March, $100 \mathrm{M}$ in June 2000- essentially in the form of temporary exemptions of pension charges. These aids were officially presented (to delude the EC) as a compensation to fishers for the damages due to the Erika oil spill of December 1999 in the Bay of Biscay. The industry was prompt to convert these into a rebate on the fuel price per litre. Locally, Regions and municipalities also contributed some aids. The second package came with the announcement of a FF $305 \mathrm{M}$ grant for fleet modernisation, through reduced loan rates, and of an unspecified buyback plan to reduce overall capacity. Port blockades resumed during summer -as the price of oil continued to rise - and reinforced by a massive rally of fishers in Paris forced the government to concede another package of aids, at an estimated cost of FF $200 \mathrm{M}$, to bring the price of diesel fuel down from FF 2.20 to 1.30 per litre. This scheme was based on actual consumption and thus mostly benefited the trawlers. No excuse was used this time to deceive the Commission, which initiated a formal inquiry procedure against France in March 2001; it enjoined the government to get reimbursement of the illicit aids from fishers, but no one has been brave enough to try (the formal ruling was proclaimed in July 2004, falling on another government facing its own episode of crisis). Eventually, following an agreement among OPEC countries to increase their production, the price of oil decreased during 2001 and remained low for the ensuing two years, releasing the crisis.

In the meantime the cooperative movement suggested to put in place a mutual insurance fund, to be financed with contributions by fishers and profits made on equity derivatives, to cover a large array of hazards, among which increases in fuel price featured in first place but possible extensions were foreseen to cover fishery closures due to exhausted quotas, market failures or pollution. It took a long time to convince the ministry of finances, but the government was finally attracted by the idea that, benefiting to individual fishers contributing in proportion to their actual consumption the scheme would not appear to a watchful EC as a sector-wide state aid, and also by the promise that the insurance would discharge authorities of any need to intervene in the fuel issue should its price rise in the future. However, the system required a seed of public money to start up, which was obtained by June 2004 ( $€ 1 \mathrm{M}$ out the $33 \mathrm{M}$ granted to Crédit Maritime for aided loan rates). This came when a new episode of crisis was lurking due to a combination of low fish prices (blamed on illegal sales of over-quota fish in the UK) and the resurgence of soaring oil prices (due to tensions in Iraq). The crisis blew up in October 2004 with a series of port blockades (again led by the Mediterranean fishers), to which the government again responded with a suite of aids. This included in the first place $€ 15 \mathrm{M}$ of "reimbursable advances" for the fuel insurance fund set up to guarantee a price of $€ 0.27$ per litre; deduction of the contribution to the fund from income taxes; tax abatements for fishers operating in international waters; case by case exemptions of pension charges. This did not prevent another eruption of riots and port blockades in April 2005 -as the price of fuel kept on rising - compelling the government to add $€ 10 \mathrm{M}$ to the fuel insurance fund. It added another $€ 40 \mathrm{M}$ in July to ease the tensions and keep the system afloat ${ }^{18}$. It also rehashed the very same incantation as in the 1980s and 1990s about the need to undertake studies on alternative energy sources and fuel saving devices.

\footnotetext{
${ }^{17}$ Another example showing that fishermen do not necessarily comply better with internally negotiated rules than with those imposed from outside. The (virtual) power limit was maintained even when the licensing system was reformed by 1993. There is also a 'fishy' collusion on this issue: the media articles or shipyards' advertisements describing new entrants to the fleet never mention the engine power when the subject is a Mediterranean trawler.

${ }^{18}$ At that time, some 2400 boats had subscribed to the insurance, but their contributions only amounted to $€ 2 \mathrm{M}$. Profits from speculations on the equity markets covered $26 \%$ of the expenses. The base price triggering compensation from the fund had to be increased slightly from $€ 0.27$ to 0.30 per litre.
} 
Apart from the fuel issue three important events occurred at that time that stirred up vexation within the industry. One was the EU decision, following the 2002 reform of the CFP, to ban all aids to the construction of new boats, except for documented crew safety or fish quality reasons. France fought hard to postpone the deadline to the end of 2004, and the delay was used to hasten a number of subsidised construction projects: in a meeting with the industry in July 2004 the minister took pride that more than 250 boats would be built and 100 modernised during 2003-2004 with the support of his programme. The industry felt badly victimised by "Brussels" when aids ended in 2005 . The other event was the EU decision to close the anchovy fishery in the Bay of Biscay for the summer and then until the end of 2005, based on evidence that the stock was below safe limits (the closure was continued into 2006 and 2007). It seriously hurt a fleet of pelagic trawlers that had received substantial aids for its expansion and had become highly dependent on anchovy for its viability. It also created a lot of turmoil in cities along the Atlantic coast despite the EU funded lay-up premiums granted to the affected boats and crews. Third came the ruling by the European Court of Justice in July 2005 fining France $€ 20 \mathrm{M}$ for lack of enforcement of regulations regarding undersized fish. The facts dated back to the early 1990s but the French authorities had disdained repeated warnings by the EU institutions $^{19}$, so the Court added a penalty of $€ 57.8 \mathrm{M}$ per semester until France proved the effectiveness of its fisheries control. Fury at the highest levels of government resulted in a sudden mobilisation of all possible enforcement bodies, and resentment by unprepared fishers who promptly protested for undue harassment. In the end French taxpayers were charged close to $€ 78 \mathrm{M}$ for this fault.

The next significant step was in April 2006, when the minister announced a $€ 100 \mathrm{M}$ package of aids -26 for decommissioning, 40 for emergency aids to enterprises, 40 for "restructuring". Although he promised to support the fuel fund, he did not specify the amount as the system was under inquiry by the EC who had already issued several warnings that it was incompatible with EU rules unless the industry did reimburse the advances, which was highly unlikely. Faced with another wave of tensions and demonstrations, the minister conceded another $€ 22 \mathrm{M}$ for the fund in May. However, the system ran out of steam, despite increases in the triggering price, and ceased by the end of the year. There was a wide consensus in the industry that boats would have gone bankrupt by the hundreds without this fuel fund, an implicit recognition that it had supported a biologically and economically unsustainable fishing effort. Noteworthy here is the imbalance between the aids for fuel (some $€ 87 \mathrm{M}$ since April 2005) and for decommissioning (€26 M, 50\% of which from EU funds). However, a novelty of the capacity buyback plans in those years was their design to selectively target the fleet segments facing major problems with their resource base (e.g. anchovy, deep sea species, bluefin tuna) and/or running costs (Mediterranean trawlers), whereas previous schemes basically worked on a voluntary and first come-first served basis.

We finish this chronicle with the strikes that erupted in October-November 2007, again sparked by rising fuel prices, and were lifted after a visit of the French President himself at the homeport of the most active leaders. He promised a 6-month exemption of social charges (worth $€ 42$ $M)$, study groups to consider modernisation of boats with fuel saving engines and, foremost, the set up of a system to compensate the price of diesel fuel above a trigger value of $€ 0.30$ per litre claimed by the industry to be the upper limit for their business to remain viable. It was enough for the boats to sail out but immediately prompted warnings by the Commission about its legality (the EC recalled that its inquiry on the previous fuel fund was ongoing and threatened that the aids would have to be reimbursed). The device imagined between the cabinet and fishers was to impose a tax -bizarrely nicknamed "eco[logical]-tax" - on fish to be paid by end consumers in shops and restaurants. A month later the Parliament enacted a $2 \%$ tax on the retail value of fish (except when bought at "small" fish shops) supposed to bring in some $€ 80-100 \mathrm{M}$ annually to the Treasury for the fuel support. Lastly, in January 2008, the ministry announced a new three-year plan with an estimated cost of $€ 310 \mathrm{M}$ (national and EU funds), the effects of which will be examined in due time. It is noteworthy that its justifications, ingredients and expectations closely resemble those of all previous plans seen throughout this review.

\footnotetext{
${ }^{19}$ The very long time required for formal procedures against states under the EU law may explain why some governments take illicit measures to save the day, leaving the consequences to be dealt with by their far remote successors.
} 


\section{Public aids, the figures}

Regrettably, an accurate reconstitution of all subsidies granted to the sector by French governments, Regions, and Europe - together with their specific object (infrastructure, investment, operation, or social) - during the 1970s and 1980s by 'mining' the media or official documents is next to impossible. Subsidies have been sort of a taboo for decades; tactical games with such dogwatches as the EC, OECD, or WTO have not helped transparency and the figures put on the public place may well have been a biased sample. Conversely, not all those promised with fanfare, notably at the time of crises to calm down hordes of irate fishers, have effectively been disbursed. For the recent period, however, things are easier as ministerial departments have to present detailed tables of their expenditures for examination by the National Assembly and the information is publicly available on the Internet ${ }^{20}$. A file on the Agriculture and Fisheries ministry's website provides a summary table of combined state and EU aids over 1991-2006, which are plotted in Fig. 4 together with the total value of French metropolitan landings. For this figure, the allocation to research and education (ca. $€ 50 \mathrm{M}$ annually) was deducted from the state aids, considering that it is not a direct support to capacity or effort. The landings values include frozen fish ( $€ 150-180 \mathrm{M}$ in recent years), mostly by tropical tuna fleets which have also been modernised with substantial aids.

The eye-catching message from this plot is that state and EU aids represent a large fraction of the sector's gross proceeds, even though the period considered is posterior to the era of intense subsidised "modernisation" during the 1980s: in many years they closely match the value of wetfish landings alone ${ }^{21}$. The proximity between aids and turnover often strikes outside observers, such as the authors of a parliamentary report [15] and of a ministerial report [16]. Only the civil service gets a similar or larger share of its budget from the taxpayers, but with strict auditing rules not imposed on fishers, and the general public is wholly unaware. It is notorious that the French agriculture sector is massively supported by state and EU funds (ca. € $28 \mathrm{bn}$ ) but, according to the ministry, these are only equivalent to $30 \%$ of the sector's turnover or to the added value. For another comparison, public aids to the UK fishing industry are in the order of its gross operating profits [17].

${ }^{20}$ http://agriculture.gouv.fr/sections/thematiques/budget-soutiens-publics/soutiens-publics-peche (last accessed June 2008).

${ }^{21}$ Note the vast difference between the current official data on subsidies and the estimates for France tabulated in Ref. [7], based on an OECD study. For that study, France tactically submitted as exemplar, from which nation-wide estimates would be extrapolated, a scallop fishery in Northern Brittany where subsidies were a marginal issue. 


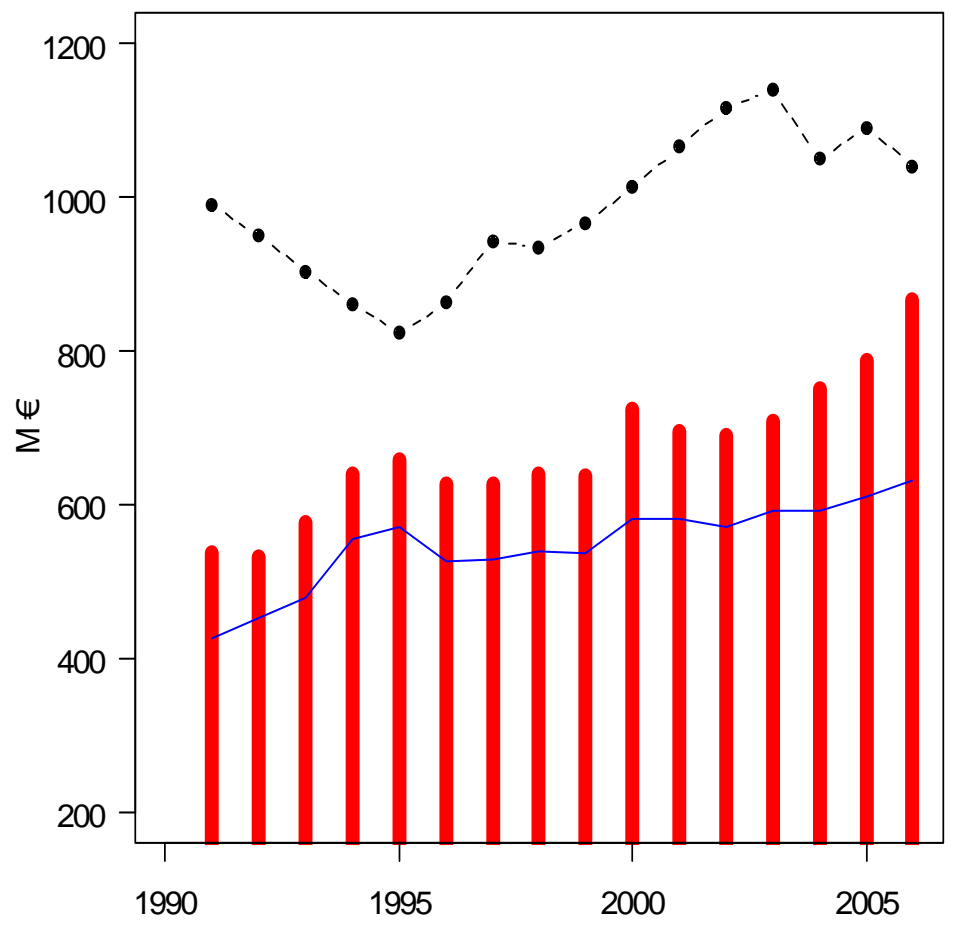

Fig. 4. Public aids (national $+\mathrm{EU}$ ) granted to the French fishing sector in 1991-2006 (bars), including state contribution to pension and health insurance (fishers only; solid line through the bars). Total value of metropolitan landings (fresh and frozen) shown for comparison (dashed line and solid circles). All values in $M €$, nominal. Sources: Ministère de l'Agriculture et de la Pêche (website) for aids, OFIMER for landings' values.

It is important to note, however, that support to the fishers' social security (health insurance and pension) makes a very large share of the French state aids (solid line across the bars in Fig. 4) ${ }^{22}$. This specific aid is seldom listed in standard inventories of subsidies by OECD (e.g. [18]) or FAO (e.g. [19]) and one may query why it is included here. A first good reason is that the ministry itself considers that it fully qualifies as a subsidy, in a context where public aids to fisheries are under attack and thus tend to be understated by governments. The other reason is that, as we have seen, permanent rebates or temporary exemptions of fishers' contributions to their social security fund (the so-called social charges) -implying a transfer to the taxpayers - have become a habitual instrument to abate crises, notably as indirect aids for fuel. Hence, there would be a serious bias in the tally of operational aids to the sector if this item was excluded. Readers may also wish to know that the seamen's social security is funded from three sources: contributions by enterprises and crews; state subsidy; and a provision from the general employees' (in private and public sectors) social security fund. The shares in 2007 were $10.5 \%, 56.2 \%$ and $31.1 \%$, respectively ${ }^{23}$; by comparison, seamen's contributions made $21 \%$ of the budget in 1994, before the government's resort to reductions of social charges as a regular tool to reduce the cost of fishing [20]. There is also a tendency for governments to stabilise the state aid while increasing the draw on the wage earners' fund: the latter has the tactical advantage of qualifying as a private donation instead of a state aid. It is also significant that in their periodic

${ }^{22}$ The ENIM (Etablissement National des Invalides de la Marine) social security is common to merchant marine crews, fishers and some shellfish farmers; the ministry's data used for the figure identify the allotment to fishers only, based on their proportion in the population of beneficiaries.

${ }^{23}$ Data from http://www.mer.gouv.fr/enim/presentation/chiffres_enim.htm (last accessed June 2008). 
attempts at bringing all pension schemes under the same rules (lately in 2007), governments have exempted the seamen's scheme.

It is equally important to keep in mind that the figures above do not include the various grants from the Regions, districts, municipalities, etc. Individually, these aids may be moderate, comparatively, but the aggregate must be significant. Unfortunately, strange as it may sound, there is no compilation of these public interventions by the central administration. Apart from an annoying lack of information, the worrying aspect of this is that local authorities may well support actions that are at odds with the national or EU fisheries policy (e.g. [21]) and the government lacks the means to identify this. Experts enrolled for the parliamentary report [15] made an attempt to gather data on local aids but only managed to get partial figures for three regions along the Atlantic coasts, for the period 19931996. Nonetheless, they came to the conclusion (p. 76) that the aggregate of EU, national and local aids exceeds the fish catching sector's turnover.

\section{Evaluation: the paradoxes}

I don't wish to dwell on the futile exercise of arguing whether subsidies are inherently good or bad. My approach instead is to track back the discourses and motivations of those who proposed the aids, and evaluate in hindsight whether the stated goals were achieved. As pointed out by Holland et al. [22], it is at least reassuring for lay citizens if programmes drawing upon the scarce resources of the public treasury achieve the intended objectives. The goals examined pertain to trade balance, competitiveness, economic performance, markets, employment and safety issues.

\section{Trade balance}

A long standing justification for aids to the sector, at both national and EU levels, has been to curb the seafood trade deficit. At times the reasoning has been made explicit as follows: our market demands $X$ tonnes of species $S$ currently sourced from foreign catches; the catch rate of a boat is $Y$ tonnes; therefore, we need $X / Y$ extra boats to cancel out the deficit [23]. Quite clearly, this never worked: despite heavy investments in fleet capacity the French trade deficit has consistently become worse in mass and value [24] -and likewise for most EU countries [2]. On the contrary, capacity investments have merely exacerbated overfishing, resulting in lower fish stocks, and reduced and more unstable landings. Finally, the domestic consumption is ever more dependent on imports: in 2004 85\% of the demand (by weight) was met by imports, vs. 69\% in 1990 [25]. The policies have been self-defeating on this account.

\section{Competitiveness}

A related argument behind public aids has often been to enhance the competitiveness of the French fishing sector relative to its foreign partners. Success here is far from clear. First, most political and industry leaders have had one single vision for the development path of the sector, which was towards the most intensive mode of exploitation, and all public programmes have favoured trawling, along with sturdy killing machines. The industrialisation of the so-called artisanal sector, as evidenced by the steep increase in average power during the 1990s (Fig. 3), is an obvious result of that policy. The flipside, though, is the high running costs of these brawny trawlers. If one adds the inherent disadvantage that French vessels have longer distances to sail to reach the productive grounds of northern Europe or West of the British Isles, competitiveness is not on their side. Moreover, the incitement of the public aid policies has pushed a number of skippers into risky indebtedness. As we have seen with some crisis episodes, this had made them particularly vulnerable to natural or economic incidents. The observation that vessels ordered or delivered in recent years, after the EU ban on construction aids, are more reasonable in terms of length, power and cost provides indirect evidence that earlier aids had encouraged oversized projects. A second aspect of competitiveness is related to markets. A distinctive trait of the French policy (pointed out in Ref. [15], for example) is that the withdrawal price system - as a support to fishers' revenues - is used more intensively than in any other EU state. Actually, for decades French POs have seen the management of that system as their primary role, whereas other EU POs focused on marketing or quota management. The system could only work with massive injection of state and EU money, with the result of making French fish more expensive at first sale than the same species on the international market. Inevitably, wholesalers and multiples turned to cheaper foreign products. Ironically, at the time of crises, French fishers have often 
accused other EU states of "unfair competition" ${ }^{24}$ for not applying the withdrawal price system, thus facilitating export of their cheaper products into the French market. In fact, this system has never been mandatory under the market area of the CFP, whereas some of the mandatory market rules (e.g. on grading and labelling) decided in 1970, that would have helped access of French products to European markets (notably via internet auctions), are as yet not uniformly implemented in France. Overall, it seems that the policies aimed at supporting investments and revenues have reduced rather than enhanced the competitiveness of the French industry.

\section{Profitability}

Improving the economic performance of fishing enterprises, and of the whole trade chain, has always ranked high among the stated objectives of public aid programmes. In English the idea would probably be captured in the noun "profitability", but there is a niggling semantic problem here. In reviewing hundreds of pages of French fishing magazines I have never encountered the word "profit" in interviews or speeches of industry members: looks like a taboo word, for administrations and politicians as well. At best, they may say that their business needs $X$ euros of landings to break even, while others (notably directors of auction markets or harbours) often express their needs in plain tonnes of fish. But the idea that the well-being of a fishing enterprise depends on its profits, not just its gross earnings, seems to be heretical in French fishery spheres. The tacit consensus is rather that fishing enterprises are special things to which the basic economic principles that may be relevant for other businesses (or for Anglophones) do not apply. The word used is "rentabilité" which, in principle, is the straight translation of "profitability" but in practice appears to incorporate a vague mix of socioeconomic notions and, in the end, is best approximated by "viability". That is, the key concern is how to make ends meet by the end of the month and merely keep the enterprise just above the borderline with bankruptcy. This is exemplified by the surreal plea in Ref. [26] ${ }^{25}$, which denies the appropriateness of hard-line economic profitability and argues for a "corrected" notion accounting for the various services (food, employment, and lively coastal communities) that fisheries provide to the nation, for which they should receive a remuneration by consumers and/or tax-payers such that fishers continue to be fishers. In brief, the goal reduces to a life or death, or viable vs. bankrupt dilemma, making the evaluation of the policies awkward. For sure, the data in Figure 4 speak for themselves: a sector that needs such amounts of aids year on year is not viable by any standard economic criterion, and its role in generating wealth for the nation is equivocal. Now, there is still a French fishing industry delivering some economic benefits locally. It is hard to imagine how the industry could look like today, under the alternative scenario of no aid to capacity building over the last few decades. Since all European countries also have been generous with aids to their fishers ${ }^{26}$, we have no exemplar of that scenario for the Northeast Atlantic bio-region. It is quite likely, nonetheless, that the sector, as it was formatted during the 1970-1980s, would only exist in vestigial form today without the constant flow of aids. In summary, if we refer to strict profitability criteria, the outcome of the policies does not conform with the expectations in the discourses. If economic performance is understood as meant by French authorities, with a distinct social slant, the results are a mixed bag.

\section{Markets}

On repeated occasions, crises were associated with low prices that were blamed on inadequacies in the seafood value chain, namely a lack of dialogue and coordination between producers and the marketing side. In 1970 POs were created at EU level precisely to improve this weak link, and this was also the main reason behind the establishment in France of the FIOM agency in 1975 [8], and of its successor OFIMER in $1999^{27}$. Substantial amounts of public funds were provided to these institutions to fulfil their mission but, as said, much of the monies served to support fishers' revenues through the withdrawal system, at the detriment of genuine reforms to organise the national seafood market. This also reveals the strong bias of the administration, and of its aid programmes, towards the catching

\footnotetext{
${ }^{24}$ In the language of French fishers competition, even from unsubsidised fisheries, is always unfair just like proposals by the European Commission are always unacceptable.

${ }^{25} \mathrm{An}$ old paper, but the author had a long career as a very influential spokesperson for the industry, notably as president of the National Committee of Fisheries during 1993-2003, and managed to have his visions endorsed by the industry, MPs and ministers.

${ }^{26}$ For example, during the 1980s, the Norwegian government and industry board negotiated the allocation of aids to the tune of NOK1-1.5 bn annually; the French magazines attentively reported on the event, with a lot of envy.

${ }^{27}$ See http://www.ofimer.fr/Pages/Ofimer/Institution.html (last accessed June 2008).
} 
sector against other segments of the industry ${ }^{28}$. The poor performance of FIOM, and of the market organisation policy in general, is bluntly criticised in the parliamentary report [15] (e.g. in the executive summary, p. 27: "on the question of whether the public fisheries policies managed to organise the trade chain, the answer is negative, without any hesitation"). Nearly ten years later, fault-finding comments on the same issues abound in a report to the Prime Minister [25], which emphasises the malfunction of key institutions (e.g. p. 31: "the gulf between POs and the consumer, and hence the market is measurable in light years"), and the general lack of attention to the market among fishers. It is rather depressing to observe, in reviewing old press articles, that issues about the producers-market link identified and put on the agenda recurrently since the 1970s are still pondered over, in the same terms, today ${ }^{29}$. This merely confirms the findings of the two official reports above, and their conclusion that the aids put in place to improve the organisation of the seafood market did not achieve their objectives. In addition, deficiencies in the market side degrade the performance under the three previous items - trade balance, competitiveness, and profitability.

\section{Employment}

Over the last thirty years (un-)employment has been a predominant concern in France and there are few policy statements that do not mention the topic in some way. Fisheries policies are no exception. The unanimous discourse in industry and political circles is that a large fleet is needed to maintain employment at sea and, by implication, in associated industries onshore; moreover, it is only with modern boats that one can attract crews to join or stay. Most public aid programmes were responsive to these two claims. Conversely, each EU initiative to curb capacity sparks outcries that "Brussels" is determined to decimate the seafarers' workforce and destroy fisheries-dependent communities. The data (Fig. 2) certainly confirm that the decommissioning programmes since the 1990s came with a severe toll on employment at sea. However, it is equally clear from the graph that the decline in employment has been a constant feature of the post-war period, while the fleet was actively modernised as desired by the industry itself: it quite happily accepted at the time that contraction of labour was part of the modernisation process through mechanisation (the classical capital-labour substitution, Fig. 3). It also accepted that aids were seldom granted directly to crews. Unfortunately, insightful analyses of the impact of policies on employment in fishing are hampered by the terrible quality of information ${ }^{30}$ (employment is a major societal problem, and if people were serious about it they should demand that means be put in place to monitor it more accurately). The data situation is even worse for indirect and induced employment, which is also a recurring argument in the discourse of those (notably local authorities) lobbying for support to the sector. Over time, multipliers in the range 3-5 jobs per seaman have been put forward (bizarrely rising while severe contractions took place in shipyards, wholesale enterprises, canneries and other processing plants); the current industry's 'guesstimate' seems to be four onshore jobs per job at sea ([25], p. 11) ${ }^{31}$. However, nationwide, the only reference with hard data is a 1992 consultant's study [27] (partially updated in 1999) which found that each job at sea generated about 1.4 jobs onshore in ancillary industries. In 2006, the Normandy

\footnotetext{
${ }^{28}$ For wholesalers, the widespread reputation is that they make enough, if not indecent, benefits on the back of hard-working fishers. Yet, this sector has gone through very painful restructuring without political compassion. Also, during the 1995 crises, motorists, shipyards and other services were left with some FF 70M of unpaid invoices to fishers and asked for consideration of their problem in the relief plan; in response they were enjoined by the ministry to wipe off the debts and make do (an unprecedented variant of subsidy).

${ }_{29}$ For example, communication of quantities on board in advance of landing, although there are signs of progress on this particular issue as POs get more involved in managing quotas and optimising the return to their members.

${ }^{30}$ One must always check whether the data include or not the overseas territories, or the shellfish farmers possessing fishing licences. There are also distinctions by time worked (typically, at least one day, three months, six months or nine months) or estimates in full-time equivalent. Nevertheless, with due account of these cases, there can be enormous inconsistencies between documents quoting the same original source, between successive updates of the same publication, and even between different pages within the same administrative document. The data communicated to Eurostat variably refer to one or another category and are useless. There was a change in the counting procedure in 2002, to avoid double counting when a seaman had worked from different ports, but the data for earlier years were not revised accordingly.

${ }_{31}$ Most documents contain open-ended incantations, with phrases like "innumerable", "considerable" or "many more" jobs generated by each fisher.
} 
Region commissioned a study and was disappointed that it found a multiplier of 1.5 only [28], in line with the previous study. The emphasis on employment, while overlooking the dilemma with modernisation, and the deliberate inflation of the job multiplier are consistent with the process brilliantly described by Brookfield et al. [29], that is the use by local politicians of the past importance of the fishing industry as an icon and branding mechanism for other purposes, such as attracting tourists or businesses. Nevertheless, the inexorable facts are that 'virtual' fisheries are no more likely to create real jobs in the fishing industry than past modernisation aids were to maintain them.

A connected issue which, quite legitimately, is very dear to the heart of the industry is the entry of young blood into the profession. There is little doubt that the expansionist policies of the 1970-1980s have facilitated the access of young skippers, notably in the artisanal sector, under conditions that their fathers would not have imagined. Times have changed since the 1990s not only because of the limitations on new aided constructions, but also because clauses of the licensing system established in 1993, based on suggestions by the industry itself, had the unwanted effect of inflating the price of second-hand vessels, the traditional first step of the ladder for candidate skippers. However, the issue is not merely one of public policy. The generation of now retiring skippers, who benefited from the generous aid policies, is among the most vociferous in demanding measures for the young fishers, and it is tempting to ask them what they really did to make the profession attractive to their children and other youngsters. Their liability is implicated in at least four areas: fish stocks are in worse shape than when they inherited them; they dismissed reforms of the market organisation, to make it fit with standards of modern economies and ensure good revenues; they resisted repeated attempts by governments to modernise the social relations in artisanal fishing enterprises (formal contracts of engagement, balanced rights and duties between skipper and crew, working conditions, hygiene and safety, etc.), which are still terribly medieval compared to the norm in onshore businesses; they refused for years the establishment of an A-level degree in marine schools -with the argument that the industry needs arms, not brains - that would have prepared candidate skippers to manage the highly capitalised business that a fishing boat is today ${ }^{32}$. As a result, only the most motivated young or those who have no choice recruit to the fishing industry. The fault of the public authorities, though, is that they did not require progress in those problem areas in exchange for the multiple aids they provided to the sector.

\section{Safety}

In France [30], like in many developed countries [31], fishing is among the professional activities with the highest casualty rate. Periodically dramatic accidents are on the news headlines and create intense emotion in coastal areas. Safety considerations are thus paramount in the plea for, and the instalment of investment aids to the sector, with the motto that safer boat means bigger, more powerful, faster. However, evaluating whether the aids have benefited safety is not straightforward. In 1997, the government established a bureau to investigate marine accidents ${ }^{33}$. In its 1999 report it pointed out that many fishing boat accidents were due to their flimsy economic situation, forcing skippers to take excessive risks. That is, indebtedness due to aided overcapitalisation was implicated. However, its subsequent reports rehash the common litany of the industry, that the root cause is the age of the vessels that can only get worse because of the restrictions on fleet renewal imposed by Brussels and scientists for the sake of resource conservation. Its earlier stance is consistent with a UK study quoted by the fishery minister in hearings before the House of Commons in 1999 [32], indicating that recent boats with indebted skippers were relatively more involved in accidents than old repaid boats. The explanatory statements of a European Parliament's resolution on safety [33] offer a middle ground: they point out economic pressure as a key factor in fishers' risk-taking attitudes, while drawing the Commission's attention on the need to account for the safety impacts when proposing capacity or catch quotas' regulations ${ }^{34}$. Since a wide variety of causes and circumstances may lead to accidents, no clear conclusion emerges as to the positive vs. negative effects of aids on occupational fatalities.

\footnotetext{
${ }^{32}$ In stark contrast with agriculture where a vast majority of young farmers have received a high degree of education, which is also a prerequisite for some aids. In fisheries schools the apprentices do not even have basic courses on accounting. The majority view in fisheries is that bookkeeping is a job for specialised offices or for the spouses.

${ }^{33}$ Bureau d'Enquêtes Accidents (BEA)-mer. Its annual reports, in French, are available online at http://www.beamer-france.org/rapports/rapports.htm

${ }^{34}$ The EuroParliament also points at France that had not yet transposed a relevant 1997 directive, some three years after the deadline.
} 
Nevertheless, a fact that strikes observers onboard French fishing boats is the proneness of crewmen for risky behaviours, and the rare uptake of individual safety equipment despite the many aids offered by governments over the years (typically, in response to each major tragedy).

\section{Social peace}

From this discussion, it appears that the success of the public aid policies in achieving the stated objectives is often equivocal and, paradoxically, that aids have exacerbated the problem they were meant to solve in some areas. Perhaps, the supreme paradox of the policies has to do with the so-called "social peace". It is notorious that the paramount objective of the French administration in charge of fisheries management is to preserve social peace, in the sense of avoiding embarrassment of the minister, vehement demonstrations in streets, damage to public equipment, harbours' blockades and other impacts on the general economy. When a crisis erupts the priority concern for authorities is to restore social peace, and the habitual expedient of granting (or promising) aids precisely has this objective. As the review shows, this piecemeal, day by day band-aids treatment has done little in the way of preventing a repetition of crises. In other words, the paradox is that the succession of crises with civil disorder that keep on recurring in the French fishing sector is the result of public aid policies whose overarching objective was to preserve social peace.

\section{Conclusion}

It is apparent from this review that public aids have become a central element in the French approach to fisheries governance. The evidence, however, is that subsidies allocated to solve short-term problems (generally blamed on easy but fallacious culprits) have done nothing to cure the root causes or to help the industry adapt to changing circumstances, and have thus paved the way for a subsequent eruption of crisis. In a nutshell, the French fishing industry has been drowned by subsidies meant to keep it afloat. Perhaps more problematic, in generating such vicious circles, than the systematic recourse to subsidies or their sheer volume is the fact that they were granted without condition. In searching documents for this review I have not encountered a case (except the extreme option of decommissioning) where aids were traded against some diligence in fishers' behaviour, be it in wiser use of marine resources, more attention to the market, improved social relations, provision of more accurate information on their activities, or stricter compliance with legal obligations in general. In other words, the aids were devised to simply continue "business as usual", with all its wrongs. Indeed, some aids have exacerbated the critical processes (open access, overcapacity, indebtedness, excessive effort, and/or non-selective fishing) identified by scholars as the drivers to disaster in fisheries management, globally. The European Court of Auditors [3] itself reckons that overcapacity (facilitated by subsidies) is a key factor in the failure of the CFP. It is widely acknowledged that successful management is largely a matter of putting in place the right incentives (e.g. [34-37]). This chronicle lends support to the proposition, albeit ad absurbum: a key feature of the French subsidy programmes is that they consistently nurtured the wrong incentives and the result is as we see, a fishing industry heading towards dereliction through a perpetual cycle of crises.

It is also apparent from this retrospective review that past lessons have not been learnt: public discourses of the industry and administration carry the very same views and incantations as thirty years ago; problems continue to be blamed on the wrong causes; the same facile solutions (some subsidies or derogations) are selected despite their clear self-defeating character; positive changes identified in debates decades ago are still dismissed whenever they imply some degree of short-term cost (compensation of those costs would have been a better use of public monies). In that sense, if the policies' objective of modernising the industry has been met in terms of equipment, they have failed with respect to the mindsets. In their plea for subsidies most actors, be they politicians, administrators, fishers or bankers, continue to use the same reasoning as for agriculture or manufacturing industries, that more inputs and machinery are needed to increase production. This proves that the myth of Mare Infinitum is still largely prevailing in French fishing circles.

During the thirty odd years spanned by this review, right- and left-wing governments have alternated, with different dogmas regarding state interventions in economic and social policies. However, it is hard to find any significant difference in their respective dealings with the fisheries sector, including its subsidisation. They seem to be all trapped in the process of industrialisation of the 
sector put in place in the post-war period, combined with long standing corporatist policies, and struggling to find an escape route with acceptable political costs. Regarding the latter, changing course on subsidisation has not yet emerged as a feasible option. Tackling the awkward issue of restrictive regulation of access to the common resources, with well-defined use rights, would probably be a good way of releasing the charge on taxpayers durably, but the few attempts so far could not resist the fierce opposition of the industry.

A disconcerting observation is that, ultimately, fishermen are the principal victims of this system of automatic aids and so unperceptive of the fact that they demand its continuation by their turbulent strikes and demonstrations. Not only they suffer the consequences in their own livelihood, but they have also lost much of the sympathy of the general public, partly due to the mournful image they give of themselves through their phraseology (crisis, failure, etc.). Moreover, French fishers have lost the consideration of their northern Europe colleagues who scorn them as "the subsidy junkies" (quoted in Ref. [38]) and sideline them in international arenas. The clear winners are the politicians ${ }^{35}$ (here meant to include "apparatchiks" of the professional representation who have influenced the French fisheries policies for years, when they did not draft them entirely). None of those who had a role in the recital of crises reviewed above was ever admonished for the poor return to the nation of the subsidies he had decided. Most even had a brilliant career.

Incidentally, I hope this review may serve to correct the widely held view that TACs are the predominant management tool under the CFP, or even its central tenet (i.a. [39]). The case treated here shows that financial measures relevant to the market or structural areas of the CFP, combined with national contributions, can be largely more determinant tools than TACs in shaping the format and operations of fishing fleets. It is also noteworthy that, in contrast to conservation measures, no scientific advice is mandated — nor desired — prior to deciding on subsidies: politicians just do it their ways, and no issue about uncertainties is ever raised (corroborating Sarewitz [40]).

\section{Acknowledgements}

Emilie Leblond (Ifremer, Brest) kindly provided the 1983-2007 fleet data used for the long-term trends plots. The data were compiled by Ifremer's SIH (Système d'Information Halieutique) programme. I extend my best thanks to Jean Boncoeur, André Forest, Marie-Joëlle Rochet, Olivier Thébaud and Verena Trenkel for their attentive reading of and thoughtful comments on earlier versions of the paper. The present text is my sole responsibility, however.

\section{References}

[1] Ruseski G. International fish wars: The strategic roles for fleet licensing and effort subsidies. Journal of Environmental Economics and Management. 1998;36(1):70-88.

[2] CEC. Green paper on the future of the common fisheries policy: Commission of the European Communities, COM(2001) 135 final; 2001.

[3] European Court of Auditors. Special Report No 7/2007 (pursuant to Article 248(4) second paragraph, EC) on the control, inspection and sanction systems relating to the rules on conservation of Community fisheries resources [together with the Commission's replies]. Available from: $<$ www.eca.europa.eu>; 2007.

[4] Holden MJ. The Common Fisheries Policy: origin, evaluation and future. Oxford: The Buckland Foundation, Fishing News Books 1994.

[5] Hilborn R. Defining success in fisheries and conflicts in objectives. Marine Policy. 2007;31(2):153-8.

[6] Beddington JR, Agnew DJ, Clark CW. Current problems in the management of marine fisheries. Science. 2007;316:1713-6.

\footnotetext{
${ }^{35}$ This also applies to the CFP, which is best described as a game devised by politicians, for the sole benefit of politicians on the back of fishermen (and fish stocks, accessorily). No surprise, then, that it is often seen as a political success and a failure in any other respect.
} 
[7] Munro GR, Sumaila UR. The impact of subsidies upon fisheries management and sustainability: the case of the North Atlantic. Fish and Fisheries. 2002;3(4):233-50.

[8] Meuriot E. La flotte de pêche française de 1945 à 1983 - Politiques et réalités. Brest: Ifremer 1985.

[9] Catanzano J, Lantz F, Vernier C, Allard M-O. La pêche artisanale des années quatre-vingts en France: Ifremer, Direction des Ressources Vivantes, RIDRV-93.032.SEM/Paris; 1993.

[10] Anon. Rapport annuel du Comité Central des Pêches Maritimes. La Pêche Maritime. 1977;1192(July):403-5.

[11] Anon. Plan pluriannuel d'investissement de la flotte de pêche. La Pêche Maritime. 1982;1249(April):187-93.

[12] Hatcher AC. Subsidies for European fishing fleets: the European Community's structural policy for fisheries 1971-1999. Marine Policy. 2000;24(2):129-40.

[13] Anon. Le plan Mellick un an après. France-Eco-Pêche. 1992;368(April):21.

[14] Mettling B, Mingasson A, Hénaff $P$, Menanteau JP. Rapport d'audit sur la situation financière des navires de pêche artisanale et des organismes d'intervention: Ministère de l'Agriculture et de la Pêche, Ministère de l'Economie; 1995.

[15] Marini P. Rapport sur les actions menées en faveur de la politique maritime et littorale de la France. Annexe 5 : la pêche: Office Parlementaire d'Evaluation des Politiques Publiques. Assemblée Nationale No 771, Sénat No 345; 1998.

[16] Centre d'analyse stratégique. Une ambition maritime pour la France - Rapport du Groupe POSÉIDON "Politique maritime de la France". Secrétariat général de la mer, Décembre 2006 2006:161 pp.

[17] Strategy Unit. Net Benefits - A sustainable and profitable future for UK fishing. UK Prime Minister Cabinet Office 2004:170 pp.

[18] Cox A, Schmidt CC. Subsidies in the OECD fisheries sector : A review of recent analysis and future directions. Paris: OECD Fisheries Division. Available from: $<$ http://www.oecd.org/dataoecd/43/40/2507604.pdf>; 2002.

[19] Schrank WE. Introducing fisheries subsidies. FAO Fisheries Technical Paper. 2003;437:52 p.

[20] Anon. Une volonté de garder le régime spécifique. Le Marin. 1994;2475(16 Dec.):35.

[21] Boncoeur J, Giguelay T. French decommissioning schemes: appraising their place in public assistance to the fishing industry and their impact on fishing capacity. A preliminary analysis: AMURE Publications. Working Papers Series. D-05-2005. Available from: <www.gdr-amure.fr>; 2005.

[22] Holland D, Gudmundsson E, Gates J. Do fishing vessel buyback programs work: A survey of the evidence. Marine Policy. 1999;23(1):47-69.

[23] Fabre P. Editorial. La Pêche Maritime. 1978;1208(Nov.):610.

[24] OFIMER. Les chiffres clés de la filière pêche et aquaculture en France - Edition 2007. Paris: OFIMER; 2007.

[25] Tanguy $H$. Les Pêches maritimes françaises : entre le défi du marché et le défi de l'aménagement du territoire: Rapport au Premier Ministre, juin 2006; 2006.

[26] Parrès A. La pêche : rentabilité classique ou finalité autre. La Pêche Maritime. 1975;1173(Dec.):811-4.

[27] Cofrepêche. Etude régionale à caractère socio-économique dans le secteur de la pêche : France (4 regional volumes): Etude pour la Commission des Communautés Européennes, DG XIV; 1992.

[28] Lavalley J. Basse-Normandie: La région veut aider la pêche et la conchyliculture. Le Marin. 200617 Nov.:8.

[29] Brookfield K, Gray T, Hatchard J. The concept of fisheries-dependent communities: A comparative analysis of four UK case studies: Shetland, Peterhead, North Shields and Lowestoft. Fisheries Research. 2005;72(1):55-69.

[30] Chauvin C, Le Bouar G. Occupational injury in the French sea fishing industry: A comparative study between the 1980s and today. Accident Analysis \& Prevention. 2007;39(1):79-85.

[31] ILO. Safety and Health in the Fishing Industry - Report for discussion at the Tripartite Meeting on Safety and Health in the Fishing Industry, Geneva, 13-17 December 1999. Geneva: International Labour Organisation. Available from: <http://www.ilo.org/public/english/dialogue/sector/techmeet/tmfi99/tmfir.htm>; 1999.

[32] House of Commons. Sea Fishing. Vol. I: Report and Proceedings of the Committee: House of Commons, Agriculture Committee 8th Report. London, The Stationery Office; 1999.

[33] Parlement Européen. Rapport sur la pêche : sécurité et causes des accidents: Commission de la pêche, PE 286.492, A5-0087/2001 final, 12 March 2001. 
[34] Munro GR. The economics of overcapitalisation and fishery resource management: A review. In: Hatcher A, Robinson C, eds. Overcapacity, Overcapitalisation and Subsidies in European Fisheries: CEMARE, University of Portsmouth, Misc. Publ. no. 44 1999:7-26.

[35] Hilborn R, Orensanz JM, Parma AM. Institutions, incentives and the future of fisheries. Philosophical Transactions of the Royal Society B-Biological Sciences. 2005;360(1453):47-57.

[36] Hilborn R, Punt AE, Orensanz J. Beyond band-aids in fisheries management: Fixing world fisheries. Bulletin of Marine Science. 2004;74(3):493-507.

[37] Grafton RQ, Arnason R, Bjorndal T, Campbell D, Campbell HF, Clark CW, et al. Incentivebased approaches to sustainable fisheries. Canadian Journal of Fisheries and Aquatic Sciences. 2006;63(3):699-710.

[38] Delaney AE, McLay HA, van Densen WLT. Influences of discourse on decision-making in EU fisheries management: the case of North Sea cod (Gadus morhua). ICES Journal of Marine Science. 2007;64(4):804-10.

[39] Daw T, Gray T. Fisheries science and sustainability in international policy: a study of failure in the European Union's Common Fisheries Policy. Marine Policy. 2005;29(3):189-97.

[40] Sarewitz D. How science makes environmental controversies worse. Environmental Science \& Policy. 2004;7(5):385-403. 